\title{
Glycyrrhiza glabra (Medicinal Plant) Research: A Scientometric Assessment of Global Publications Output during 1997-2016
}

\author{
B. M. Gupta', K. K. Mueen Ahmed², Ritu Gupta ${ }^{3}$
}

B. M. Gupta ${ }^{1}$,

K. K. Mueen Ahmed', Ritu Gupta ${ }^{3}$

${ }^{1} 1173$ Sector 15, Panchkula 134 113,

Haryana, INDIA.

2Phcog.Net and SciBiolMed.Org,

Bengaluru, Karnataka, INDIA.

${ }^{3} 1 \mathrm{~K} / \mathrm{A}$ Arjun Nagar, Safdarjang Enclave, New Delhi 110029, INDIA.

\section{Correspondence:}

Ritu Gupta 1K/A Arjun Nagar, Safdarjang Enclave, New Delhi 110029, INDIA.

E-mail: ritu7648@gmail.com

\section{History}

- Submission Date: 29-05-2018;

- Review completed: 16-06-2018;

- Accepted Date: 09-06-2018

\section{DOI : 10.5530/pj.2018.6.180}

Article Available online

http://www.phcogj.com/v10/i6

\section{Copyright}

(C) 2018 Phcog.Net. This is an openaccess article distributed under the terms of the Creative Commons Attribution 4.0 International license.

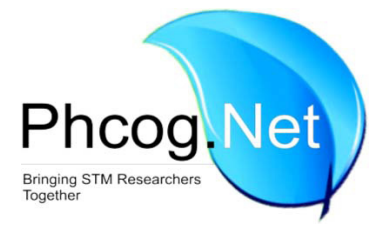

\begin{abstract}
The present study examined 3428 global publications in Glycyrrhiza glabra, as covered in multidisciplinary Scopus bibliographical database during 1997-2016, with a view to understand their growth rate, global share, citation impact, international collaborative papers share, distribution of publications by broad subjects, productivity and citation profile of top organizations and authors, preferred media of communication and bibliographic characteristics of high cited papers. The global publications registered an annual average growth rate of $10.87 \%$ and its citation impact averaged to 19.09 citations per paper. Among the top 12 most productive countries, the global share ranged from $1.87 \%$ to $19.81 \%$, with China contributing the largest share of $19.81 \%$, followed by India $(13.71 \%)$, USA $(11.84 \%)$, etc. More than $79.0 \%$ of the cumulative global publication share comes from top 12 countries during 1997-2016, showing decrease from $100.0 \%$ to $77.80 \%$ from $1997-2006$ to $2007-16$. Seven countries registered relative citation index above the world average of 1.10: U.K. (2.39), USA (1.87), Canada (1.71), Italy (1.51), Japan (1.49), Turkey (1.24) and Taiwan (1.18) during 1997-2016. Medicine, among seven broad subjects, contributed the largest publications share of $44.41 \%$, followed by pharmacology, toxicology and pharmaceutics $(35.04 \%)$, biochemistry, genetics and molecular biology $(26.84 \%)$, agricultural and biological sciences $(16.89 \%)$, chemistry $(14.59 \%)$, etc. during 1997-16. Among various organizations and authors contributing to global Glycyrrhiza glabra research, the 20 most productive global organizations and authors together contributed $15.08 \%$ and $9.16 \%$ global publication share respectively and $14.57 \%$ and $16.62 \%$ global citation share respectively during 1997-16. Amongst 3322 journal papers (in 1153 journals) in global Glycyr rhiza glabra research, the top 20 most productive journals contributed $16.80 \%$ share of total journal publication output during 1997-2016. One hundred thirteen (113) publications were found to be high cited, as they registered citations from 100 to 852 during 1997-2016 and they together received 22234 citations, which averaged to 196.76 citations per paper.
\end{abstract}

Key words: Glycyrrhiza glabra, Medicinal plant, Global research output, Scientometrics, Bibliometrics.

\section{INTRODUCTION}

Medicinal plants are of great importance to the health of individuals and communities. The medicinal value of these plants lies in some chemical substances that produce a definite physiological action on the human body. The most important of these bioactive constituents of plants are triterpenoid saponin, flavonoids, tannins, alkaloids and phenolic compounds. Many of these indigenous medicinal plants are used as a spices and food plant. They are also sometimes added to foods meant for pregnant and nursing mothers for medicinal purposes. ${ }^{1}$

Glycyrrhiza is a genus of about 20 species and a member of the pea and bean family (Leguminosae/Fabaceae), with a sub-cosmopolitan distribution in Asia, Australia, Europe, and the Americas. Its scientific name is taken from the Greek for sweet root (glykys, meaning sweet, and rhiza, meaning root)..$^{2-3}$ Glycyrrhiza glabra (known as Liquorice in English, Mulethi in Hindi and also called Yashtimadhu in Ayurveda), is an important herb used in Indian medicines, home remedies, folk medicines and Ayurveda.

Liquorice (British English) or licorice (American English) is the root of Glycyrrhiza glabra from which a sweet flavour can be extracted. It is cultivated for its rhizomes that contain the compound glycyrrhizin, which is 50 times sweeter than sugar..$^{2-3}$ Phytochemical analysis of Glycyrrhiza glabra root extract showed that it contains saponin triterpenes (glycyrrhizin, glycyrrhetinic acid and liquirtic acid), flavonoids (liquirtin, isoflavonoids and formononetin) and other constituents such as coumarins, sugars, amino acids, tannins, starch, choline, phytosterols and bitter principles. ${ }^{4}$

Cite this article: Gupta BM, Mueen Ahmed KK, Gupta R. Glycyrrhiza glabra (Medicinal Plant) Research: A Scientometric Assessmentof Global Publications Output during 1997-2016. Pharmacog J. 2018;10(6):1067-75. 
Glycyrrhiza glabra is a plant used in in herbalism and traditional medicine across the world for its ethnopharmacological value. It is found to contain important phytoconstituents, which are effectively used as antiinflammatory, anti-bacterial, anti-fungal, anti-diabetic, antiviral, antiulcer, antitussive, anti-oxidant, skin whitening, anti-diuretic agent. Its roots were also demonstrated to have antidepressant, hypotensive hepatoprotective, spasmolytic, memory strengthening activity. Licorice roots are used for its demulcent property. ${ }^{5-6}$

This plant species is reported in the literature for its biological activities such as: anti-inflammatory and expectorant, controls coughing and has hormonal effects. It detoxifies and protects the liver. Medicinally, it is used internally for Addison's disease asthma, bronchitis, peptic ulcer, arthritis, allergic complaints and steroid therapy. Externally, liquorices are used for eczema, herpes and shingles. Since, liquorice extract is used in auto-immune conditions and has therapeutic benefit in immunodeficiency conditions like AIDS. Components of licorice root have both estrogenic and anti-estrogenic activity. It is thus, an important herb for treating hormone-related female problems. It is used as an energy tonic, particularly for the spleen and stomach, and the root is added to many formulae. Roots of Glycyrrhiza glabra being tonic, demulcent laxative emollient are used in genito-urinary diseases. It is also useful in gout, asthma, sore throat, tonsillitis, flatulence, sexual debility, epilepsy, hyperdypsia, fever, coughs, skin diseases, swellings, acidity, leucorrhoea, bleeding, jaundice, hiccough, hoarseness, and vitiated conditions of vata dosha, gastralgia, cephalalgia, ophthalmopathy and pharyngodnia. Licorice is an important ingredient in medicinal oils for epilepsy, paralysis, rheumatism, haemorrhagic diseases. It is also used in the treatment of diarrhoea, fevers, fever with delirium and anuria. ${ }^{7}$

Historically, the dried rhizome and root of this plant were employed medicinally by the Egyptian, Chinese, Greek, Indian, and Roman civilizations as an expectorant and carminative. In modern medicine, licorice extracts are often used as a flavoring agent to mask bitter taste in preparations, and as an expectorant in cough and cold preparations. Licorice extracts have been used for more than 60 years in Japan to treat chronic hepatitis, and also have therapeutic benefit against other viruses, including human immunodeficiency virus (HIV), cytomegalovirus (CMV), and Herpes simplex. ${ }^{4}$

\section{Literature Review}

Only one scientometric study had been published so far on Glycyrrhiza glabra by Shri Ram, ${ }^{8}$ which assessed the research output of liquorice, indexed in Scopus database during 1993-2013. It assessed the characteristics of liquorice publications including publication distribution by countries, journals and authors. It also identified the distribution of publications by subject categories and analysed the keywords associated with liquorice research. There are only few other scientometric studies available in the past, which quantitatively analyze global and Indian literature on individual medicinal plants, such as Aloe Vera, ${ }^{9}$ Artemisinin, ${ }^{10}$ Azadirachta indica ${ }^{11}$ and Phonix dactyl lifra. ${ }^{12-13}$

\section{OBJECTIVES}

The main objectives of this study are to study the performance of Glycyrrhiza glabra research during 1997-16, based on publications output covered in Scopus database. In particular, the study focuses on the following objectives: (i) To study the growth of world and top 12 most productive countries research output in Glycyrrhiza glabra research, its citation impact and international collaborative publication share; (ii) To study the global research output by broad subject areas and the dynamics of its growth and decline; (iv) To study the trends in Glycyrrhiza glabra research by identifying significant keywords; (v) To study the publication productivity and citation impact of top 20 most productive organi- zations and authors;(vi) To study the leading modes of communication in research and (vii) to study the characteristics of top 113 highly cited papers.

\section{METHODOLOGY}

The study retrieved and downloaded 20-year publication data in Glycyrrhiza glabra research from the Scopus database (http://www.scopus.com) covering the period 1997-2016. Keywords, such as "Glycyrrhiza glabra or liquoric or licorice or glycyrrhizie acid' was incorporated in the search string and qualified these keywords with "TITLE-ABS-KEY" tag and in addition incorporated in this search string the period '1997-16' within "date range tag". Finally, this search string was applied first for searching global publication data on Glycyrrhiza glabra and then further restricted to individual country by name in "country tag" to ascertain publication output of top 12 most productive countries (including India) in Glycyrrhiza glabra research.The search string was subsequently refined, using analytical functions and tags in Scopus database, by "subject area tag", "country tag", "source title tag", "journal title name" and "affiliation tag", to get data/information on the distribution of publications output by subject, collaborating countries, author-wise, organization-wise and journal-wise, etc. For citation data, citations to publications were also collected from date of publication till 19 January 2018.

(TITLE-ABS-KEY(liquorice) OR TITLE-ABS-KEY(glycyrrhiza glabra) OR TITLE-ABS-KEY(licorice) OR TITLE-ABS-KEY(glycyrrhizie acid)) AND PUBYEAR > 1996 AND PUBYEAR $<2017$

\section{ANALYSIS}

The total research output of the world in field of Glycyrrhiza glabra cumulated to 3428 publications in 20 years during 1997-2016. The annual output of the world in Glycyrrhiza glabra research increased from53 in the year 1997 to 329 publications in the year 2016, registering $10.87 \%$ growth per annum. The cumulative world output in Glycyrrhiza glabra research in 10 years 1997-2006increased from 901 to 2527 publications during succeeding 10-year period 2007-16, registering $180.47 \%$ growth. Of the total global publications output, $81.80 \%$ (2804)appeared as articles, $11.35 \%$ (389) as reviews, $2.51 \%$ (86) as conference papers, $1.28 \%$ (44) as letters, $1.14 \%$ (39) as book chapters, $0.55 \%$ (19) as short surveys, $0.53 \%(18)$ as notes, $0.32 \%(11)$ as editorials, $0.26 \%$ (9) as erratum, $0.09 \%(3)$ each as books, conference reviews and articles in press. The citation impact of global publications on Glycyrrhiza glabra researchin 20 years averaged to 19.09 citations per publication (CPP) during 19972016; ten-yearly impact averaged to 38.67CPP for the period 1997-2006, which sharply declined to $12.10 \mathrm{CPP}$ in the succeeding ten-year 20072016 (Table 1).

\section{TOP 12 MOST PRODUCTIVE COUNTRIES IN GLYCYRRHIZA GLABRA RESEARCH}

The global research output in the field of Glycyrrhiza glabra research had originated from 94 countries during 1997-2016, of which, 60 published 1-10 paperseach in 20 years, 20 countries $11-50$ papers each, 6 countries 51-100 papers each and 8 counties 132 to 679 papers each. The top 12 most productive countries in Glycyrrhiza glabra research contributed 64 to 679 publications each during 1997-2016 (Table 2). The top 12 most productive countries in Glycyrrhiza glabra research accounted for 79.18\% global publicationshare and $84.94 \%$ citation share during 1997 2016.Their ten-yearly output accounted for $100.0 \%$ global publication share during 1997-2006 which decreasedto $77.80 \%$ during succeeding ten-year period 2007-16. Country-wise, the global publication shares of top 12 countries varied widely $1.87 \%$ to $19.81 \%$ during $1997-16$, with China accounting for the highest publication share (19.81\%), followed 
Table 1: World Output in Glycyrrhiza glabra Research, 2007-16.

\begin{tabular}{|c|c|c|c|}
\hline \multirow{2}{*}{$\begin{array}{c}\text { Publication } \\
\text { Period }\end{array}$} & \multicolumn{3}{|c|}{ World } \\
\hline & TP & TC & CPP \\
\hline 1997 & 53 & 2478 & 46.75 \\
\hline 1998 & 58 & 2752 & 47.45 \\
\hline 1999 & 57 & 2200 & 38.60 \\
\hline 2000 & 76 & 4892 & 64.37 \\
\hline 2001 & 74 & 2871 & 38.80 \\
\hline 2002 & 76 & 3145 & 41.38 \\
\hline 2003 & 112 & 3822 & 34.13 \\
\hline 2004 & 126 & 4241 & 33.66 \\
\hline 2005 & 122 & 4776 & 39.15 \\
\hline 2006 & 147 & 3663 & 24.92 \\
\hline 2007 & 151 & 3985 & 26.39 \\
\hline 2008 & 188 & 4458 & 23.71 \\
\hline 2009 & 204 & 3789 & 18.57 \\
\hline 2010 & 249 & 4149 & 16.66 \\
\hline 2011 & 262 & 3591 & 13.71 \\
\hline 2012 & 279 & 3276 & 11.74 \\
\hline 2013 & 282 & 3092 & 10.96 \\
\hline 2014 & 305 & 2089 & 6.85 \\
\hline 2015 & 278 & 1357 & 4.88 \\
\hline 2016 & 329 & 801 & 2.43 \\
\hline $1997-2006$ & 901 & 34840 & 38.67 \\
\hline 2007-2016 & 2527 & 30587 & 12.10 \\
\hline $1997-2016$ & 3428 & 65427 & 19.09 \\
\hline
\end{tabular}

$\mathrm{TP}=$ Total Papers; TC=Total Citations; $\mathrm{CPP}=$ Citations Per Paper by India (13.71\%), USA (10.72\% share), Japan (8.66\%), South Korea (6.59\%), Iran (5.72\%) and Germany (4.38\%). The other 8 countries contributed their global publication share between $1.87 \%$ to 3.85 in 20 years during 1997-16. The global publication share registered a decreasing publication share varying from $0.83 \%$ to $4.76 \%$ in 11 countries, except for increase in Iran in ten years period (1997-2006 and 2007-16).Seven oftop 12 countries scored relative citation index above the world average of 1.10: U.K. (2.39), USA (1.87), Canada (1.71), Italy (1.51), Japan (1.49), Turkey (1.24) and Taiwan (1.18) during 1997-2016. India has though emerged as one of the world leaders in Glycyrrhiza glabra research, its performance in terms of relative citation index has below the world average (0.68).

\section{INTERNATIONAL COLLABORATION}

The international collaborative output of top 12 most productive countries in Glycyrrhiza glabra research as a national share in the country-wise output varied widely from $6.12 \%$ to $42.55 \%$, with highest share coming from U.K. (42.55\%), followed by Canada (42.19\%), USA (35.96\%), Germany (29.33\%), Italy (21.97\%), Japan (19.19\%), South Korea (19.03\%), Turkey (17.24\%), China (13.84\%), Taiwan, India and Iran (from $6.12 \%$ to $9.09 \%$ ) during 1997-16. Most surprisingly, India's international collaborative share in its national output in Glycyrrhiza glabra research has been comparatively small and marginal, 8.09

\section{SUBJECT-WISE DISTRIBUTION OF RESEARCH OUTPUT}

The global Glycyrrhiza glabra research output published during 1997-16 is distributed across twelve sub-fields (as identified in Scopus database classification), with medicine accounting for the highest publications share $(44.41 \%)$, followed by pharmacology, toxicology and pharmaceutics (35.04\%), biochemistry, genetics and molecular biology (26.84\%), agricultural and biological sciences (16.89\%), chemistry (14.59\%), and other 7 sub-fields contribution varying from $0.90 \%$ to $4.99 \%$ during

Table 2: Global Publication Share of Top 12 Most Productive Countriesin Glycyrrhiza glabra during 1997-2016.

\begin{tabular}{|c|c|c|c|c|c|c|c|c|c|c|c|c|c|}
\hline \multirow[t]{2}{*}{ S.No } & \multirow{2}{*}{$\begin{array}{l}\text { Name of the } \\
\text { Country }\end{array}$} & \multicolumn{3}{|c|}{ Number of Papers } & \multicolumn{3}{|c|}{ Share of Papers } & TC & CPP & $\mathrm{HI}$ & ICP & $\% I C P$ & $\mathrm{RCl}$ \\
\hline & & 1997-2006 & 2007-2016 & 1997-2016 & 1997-2006 & 2007-2016 & 1997-2016 & \multicolumn{6}{|c|}{ 1997-2016 } \\
\hline 1 & China & 187 & 492 & 679 & 20.75 & 19.47 & 19.81 & 7922 & 11.67 & 42 & 94 & 13.84 & 0.61 \\
\hline 2 & India & 153 & 317 & 470 & 16.98 & 12.54 & 13.71 & 6119 & 13.02 & 37 & 38 & 8.09 & 0.68 \\
\hline 3 & USA & 135 & 271 & 406 & 14.98 & 10.72 & 11.84 & 14460 & 35.62 & 59 & 146 & 35.96 & 1.87 \\
\hline 4 & Japan & 82 & 215 & 297 & 9.10 & 8.51 & 8.66 & 8475 & 28.54 & 49 & 57 & 19.19 & 1.49 \\
\hline 5 & South Korea & 91 & 135 & 226 & 10.10 & 5.34 & 6.59 & 4096 & 18.12 & 35 & 43 & 19.03 & 0.95 \\
\hline 6 & Iran & 50 & 146 & 196 & 5.55 & 5.78 & 5.72 & 2880 & 14.69 & 24 & 12 & 6.12 & 0.77 \\
\hline 7 & Germany & 45 & 105 & 150 & 4.99 & 4.16 & 4.38 & 3159 & 21.06 & 31 & 44 & 29.33 & 1.10 \\
\hline 8 & Italy & 41 & 91 & 132 & 4.55 & 3.60 & 3.85 & 3811 & 28.87 & 33 & 29 & 21.97 & 1.51 \\
\hline 9 & U.K. & 31 & 63 & 94 & 3.44 & 2.49 & 2.74 & 4286 & 45.60 & 34 & 40 & 42.55 & 2.39 \\
\hline 10 & Turkey & 38 & 49 & 87 & 4.22 & 1.94 & 2.54 & 2064 & 23.72 & 24 & 15 & 17.24 & 1.24 \\
\hline 11 & Taiwan & 24 & 42 & 66 & 2.66 & 1.66 & 1.93 & 1488 & 22.55 & 25 & 6 & 9.09 & 1.18 \\
\hline \multirow[t]{4}{*}{12} & Canada & 24 & 40 & 64 & 2.66 & 1.58 & 1.87 & 2092 & 32.69 & 21 & 27 & 42.19 & 1.71 \\
\hline & Total & 901 & 1966 & 2867 & 100.00 & 77.80 & 83.63 & 60852 & 21.22 & 34.5 & 551 & 19.22 & 1.11 \\
\hline & World & 901 & 2527 & 3428 & & & & 65427 & 19.09 & & & & \\
\hline & $\begin{array}{l}\text { Share of } 12 \\
\text { Countries in } \\
\text { World Total }\end{array}$ & 100.0 & 77.80 & 83.63 & & & & 93.01 & & & & & \\
\hline
\end{tabular}

TP=Total Papers; TC=Total Citations; $\mathrm{CPP}=$ Citations Per Paper; HI=h-index; ICP=International Collaborative Papers; RCI=Relative Citation Index 
Table 3: Subject-Wise Breakup of Global Publications in Glycyrrhiza glabra Research during 1997-2016.

\begin{tabular}{|c|c|c|c|c|c|c|c|c|c|}
\hline \multirow[t]{2}{*}{ S.No } & \multirow[t]{2}{*}{ Subject* } & \multicolumn{3}{|c|}{ Number of Papers (TP) } & \multicolumn{2}{|c|}{ Activity Index } & \multirow[t]{2}{*}{ TC } & \multirow{2}{*}{$\begin{array}{c}\text { CPP } \\
1997-2016\end{array}$} & \multirow[t]{2}{*}{$\%$ TP } \\
\hline & & $1997-2006$ & 2007-16 & $1997-16$ & 1997-2006 & 2007-16 & & & \\
\hline 1 & Medicine & 417 & 1102 & 1519 & 104.45 & 98.41 & 29008 & 19.10 & 44.31 \\
\hline 2 & $\begin{array}{l}\text { Pharmacology, } \\
\text { Toxicology and } \\
\text { Pharmaceutics }\end{array}$ & 282 & 919 & 1201 & 89.34 & 103.80 & 23972 & 19.96 & 35.04 \\
\hline 3 & $\begin{array}{l}\text { Biochemistry, } \\
\text { Genetics and } \\
\text { Molecular Biology }\end{array}$ & 264 & 656 & 920 & 109.18 & 96.73 & 23022 & 25.02 & 26.84 \\
\hline 4 & $\begin{array}{l}\text { Agricultural and } \\
\text { Biological Sciences }\end{array}$ & 130 & 449 & 579 & 85.42 & 105.20 & 10456 & 18.06 & 16.89 \\
\hline 5 & Chemistry & 125 & 375 & 500 & 95.12 & 101.74 & 11459 & 22.92 & 14.59 \\
\hline 6 & $\begin{array}{l}\text { Immunology and } \\
\text { Microbiology }\end{array}$ & 36 & 135 & 171 & 80.10 & 107.10 & 3804 & 22.25 & 4.99 \\
\hline 7 & $\begin{array}{l}\text { Chemical } \\
\text { Engineering }\end{array}$ & 21 & 119 & 140 & 57.07 & 115.31 & 2343 & 16.74 & 4.08 \\
\hline 8 & $\begin{array}{l}\text { Environmental } \\
\text { Science }\end{array}$ & 22 & 93 & 115 & 72.78 & 109.70 & 2510 & 21.83 & 3.35 \\
\hline 9 & Engineering & 10 & 82 & 92 & 41.36 & 120.91 & 723 & 7.86 & 2.68 \\
\hline 10 & Neurosciences & 10 & 45 & 55 & 69.18 & 110.99 & 1209 & 21.98 & 1.60 \\
\hline 11 & Dentistry & 3 & 29 & 32 & 35.67 & 122.94 & 323 & 10.09 & 0.93 \\
\hline \multirow[t]{2}{*}{12} & Veterinary Science & 4 & 27 & 31 & 49.09 & 118.15 & 137 & 4.42 & 0.90 \\
\hline & World Output & 901 & 2527 & 3428 & & & 65427 & 19.09 & \\
\hline
\end{tabular}

- There is overlapping of literature covered under various subjects

TP=Total Papers; $\mathrm{TC}=$ Total Citations; $\mathrm{CPP}=$ Citations Per Paper

1997-16. Its activity index, which computes change in research activity in the disciplineover time1997-2006 to 2007-16 (world average activity index of a given subject is taken as 100), witnessed increase in pharmacology, toxicology and pharmaceutics (from 89.34 to 103.80), agricultural and biological sciences (from 85.42 to 105.20), chemistry (from 95.12 to 101.74), immunology and microbiology (from 80.10 to 107.10), chemical engineering (from 57.07 to 115.31 ), environmental science (from 72.78 to 109.70), engineering (from 41.36 to 120.91 ), neurosciences (from 69.18 to 110.99 ), dentistry (from 35.67 to 122.94 ) andveterinary science (from 49.09 to 118.15), as against decline of research activity in medicine (from 104.45 to 98.41 ) andbiochemistry, genetics and molecular biology (from 109.18 to 96.73) from 1997-2006 to 2007-16. Biochemistry, genetics and molecular biology, among various subjects registered the highest citations impact per paper of $25.02 \mathrm{CPP}$, followed by chemistry (22.92), immunology and microbiology (22.25), neurosciences (21.98), environmental science (21.83), pharmacology, toxicology and pharmaceutics (19.96), medicine (19.10), agricultural and biological sciences (18.06), chemical engineering (16.74), dentistry (10.09), engineering (7.86) and veterinary science(4.42) during 1997-16(Table 3).

\section{PROFILE OF TOP 20 MOST PRODUCTIVE GLOBAL ORGANIZATIONS}

Six Hundred Ninety-eight (698) organizations participated in global research on Glycyrrhiza glabra during 1997-16, of which 487 organizations contributed 1-5 papers each, 151 organizations 6-10 papers each, 45 organizations 11-20 papers each, 11 organizations 21-30 papers each and 4 organizations 31-46 papers each. The productivity of top 20 most productive global organizationsin Glycyrrhiza glabra research varied from 18 to 46 publications and together they contributed $15.08 \%$ (517) publication share and $14.57 \%$ (9530) citation share during 1997-2016.
The scientometric profile of these top 20 organizations is presented in Table 4.

Seven of these organizations registered publications output greater than the group average of 25.85: Beijing University of Chinese Medicine, China (46 papers), Hallym University, South Korea (39 papers), Seoul National University, South Korea (37 papers), Tehran University of Medical Sciences, Iran (34 papers), China Pharmaceutical University, China (29 papers), Peking University, China (28 papers) and, University of Illinois at Chicago, USA (26 papers) during 1997-2016;

Tenorganizations registeredcitation impact above the group average of 18.43citations per publication during 1997-16:University of Padua, Italy (38.57), Gifu Pharmaceutical University, Japan (37.55), University of Illinois at Chicago, USA (34.08), Hallym University, South Korea (29.08), Kaneka Corporation, Osaka, Japan (26.70), Tehran University of Medical Sciences, Iran (25.53), Seoul National University, South Korea (22.0), Korea Food Research Institute, South Korea (20.19), China Pharmaceutical University, China (19.69) and China Medical University Taichung, Taiwan (18.52);

Nine organizations contributed international collaborative publications share above the group average of $10.64 \%$ : Seoul National University, South Korea (24.32\%), Korea Food Research Institute, South Korea (23.81\%), Gifu Pharmaceutical University, Japan (20.0\%), China Pharmaceutical University, China (17.24\%),Kyungpook National University, South Korea (16.67\%), China Agricultural University, Beijing, China (16.0\%), University of Padua, Italy (14.29\%), University of Illinois at Chicago, USA (11.54\%) and Zhejiang University, China (11.11\%) during 1997-2016;

Nine organizations registered the relative citation index above the group average (0.97) of all organizations: University of Padua, Italy (2.02), Gifu Pharmaceutical University, Japan (1.97), University of Illinois at Chi- 
Table 4: Scientometric Profile of Top 20 Most Productive Global Organizationsin Glycyrrhiza glabra Research during 1997-2016.

\begin{tabular}{|c|c|c|c|c|c|c|c|c|}
\hline S.No & Name of the Organization & TP & TC & CPP & HI & ICP & $\%$ ICP & $\mathrm{RCl}$ \\
\hline 1 & Beijing University of Chinese Medicine, China & 46 & 219 & 4.76 & 8 & 0 & 0.00 & 0.25 \\
\hline 2 & Hallym University, South Korea & 39 & 1134 & 29.08 & 20 & 4 & 10.26 & 1.52 \\
\hline 4 & Tehran University of Medical Sciences, Iran & 34 & 868 & 25.53 & 8 & 3 & 8.82 & 1.34 \\
\hline 5 & China Pharmaceutical University, China & 29 & 571 & 19.69 & 12 & 5 & 17.24 & 1.03 \\
\hline 7 & University of Illinois at Chicago, USA & 26 & 886 & 34.08 & 13 & 3 & 11.54 & 1.79 \\
\hline 8 & China Agricultural University, Beijing, China & 25 & 223 & 8.92 & 7 & 4 & 16.00 & 0.47 \\
\hline 9 & China Academy Chines Medical Science, Beijing, China & 25 & 125 & 5.00 & 6 & 0 & 0.00 & 0.26 \\
\hline 10 & Nanjing University of Traditional Chinese Medicine, China & 23 & 204 & 8.87 & 9 & 1 & 4.35 & 0.46 \\
\hline 11 & China Medical University Taichung, Taiwan & 23 & 426 & 18.52 & 13 & 2 & 8.70 & 0.97 \\
\hline 15 & Korea Food Research Institute, South Korea & 21 & 424 & 20.19 & 11 & 5 & 23.81 & 1.06 \\
\hline 16 & Kaneka Corporation, Osaka, Japan & 20 & 534 & 26.70 & 13 & 0 & 0.00 & 1.40 \\
\hline 17 & Gifu Pharmaceutical University, Japan & 20 & 751 & 37.55 & 12 & 4 & 20.00 & 1.97 \\
\hline 18 & Zhejiang University, China & 18 & 296 & 16.44 & 10 & 2 & 11.11 & 0.86 \\
\hline 19 & Peking Union Medical College, China & 18 & 102 & 5.67 & 7 & 1 & 5.56 & 0.30 \\
\hline \multirow[t]{4}{*}{20} & Kyungpook National University, South Korea & 18 & 244 & 13.56 & 11 & 3 & 16.67 & 0.71 \\
\hline & Total of 20 organizations & 517 & 9530 & 18.43 & 10.95 & 55 & 10.64 & 0.97 \\
\hline & Total of World & 3428 & 65427 & 19.09 & & & & \\
\hline & Share of top 20 organizations in World total output & 15.08 & 14.57 & & & & & \\
\hline
\end{tabular}

$\mathrm{TP}=$ Total Papers; TC=Total Citations; $\mathrm{CPP}=$ Citations Per Paper; HI=h-index; ICP=International Collaborative Papers; RCI=Relative Citation Index

cago, USA (1.79), Hallym University, South Korea (1.52), Kaneka Corporation, Osaka, Japan (1.40), Tehran University of Medical Sciences, Iran (1.34), Seoul National University, South Korea (1.15), Korea Food Research Institute, South Korea (1.06) and China Pharmaceutical University, China (1.03) during 1997-2016.

\section{PROFILE OF TOP 20 MOST PRODUCTIVE AUTHORS}

One thousand and sixtyeight (1068) authors participated in global researchon Glycyrrhiza glabra during 1997-16, of which 967 authors contributed 1-5 papers each, 81 authors 6-10 papers each, 16 authors 11-20 papers eachand 4 authors21-26 papers each. The research productivity in the field of Glycyrrhiza glabra research of top 20 most productive authors varied from 11 to 26 publications. Together they contributed $9.16 \%$ (314) global publication share and 16.62\% (10876) citation share during 1997-16. The scientometric profile of these 20 authors is presented in Table 5.

Nine authors registered publications output above the group average of 15.7: S.S. Lim (26 papers), J.H.Y. Park (23 papers), D.A. Armanini and M. Ye (21 papers each), H. Hayashi (20 papers), E. Yarnell (18 papers), J. Bielenberg and C. Fiore (16 papers each) during 1997-2016;

Seven authors registered impact above the group average of 34.64citations per publication:M. Aviram (120.58), J. Vaya(92.5), I.C. Haznedaroglu (61.62), S. Tamir (55.0), C. Fiore(48.75), R.B. Breemen (43.92) and D.A. Armanini (41.33) during 1997-2016;
Nine authors contributed international collaborative publications share above the group average of $10.19 \%$ of all authors:W. Li (27.27\%), H. Hayashi (20.0\%), J. Vaya (18.75\%), C. Fiore and J. Bielenberg $(18.75 \%$ each), S. Tamir (18.18\%), D.A. Armanini , J.H.Y. Park (13.04\%) and S.S. Lim (11.54\%) during 1997-2016;

Seven authors registered the relative citation index above the group average (1.81) of all authors: M. Aviram (6.32), J. Vaya (4.85), I.C. Haznedaroglu (3.23), S. Tamir (2.88), C. Fiore (2.55), R.B. Breemen (2.30) and D.A. Armanini (2.17) during 1997-2016.

\section{MEDIUM OF RESEARCH COMMUNICATION}

Of the total world output on Glycyrrhiza glabra research, 96.91\% (3322) appeared in journals, $1.20 \%$ (41) in books, $0.90 \%$ (31) in book series, $0.70 \%(24)$ in conference proceedings, $0.26 \%(9)$ as trade publications and $0.03 \%$ (1) as unidentified during 1997-16. 3322 journal papers appeared in 1153 journals, of which 1110 journals published 1-10 papers each, 30 journals 11-20 papers each and 13 journals 21-64 papers each during 1997-2016. The top 20 most productive journals reported 16 to 64 papers each on Glycyrrhiza glabra research; togetherthey accounted for $16.80 \%$ (558 papers) of total Glycyrrhiza glabra output published in journals during 1997-16. Glycyrrhiza glabra research being reported increasingly in journals is gradually becoming a trend; for example, the top 20 most productive journals in ten years has shown decline in their Glycyrrhiza glabra output from $18.74 \%$ to $16.09 \%$ share between $1997-2006$ and 2007-16. The topranking journal is Journal of Ethnopharmacology (with 64 papers), followed by Phototherapy Research (50 papers), Jour- 
Table 5: Scientometric Profile of Top 20 Most Productive Authorsin Glycyrrhiza glabra Research during 1997-16.

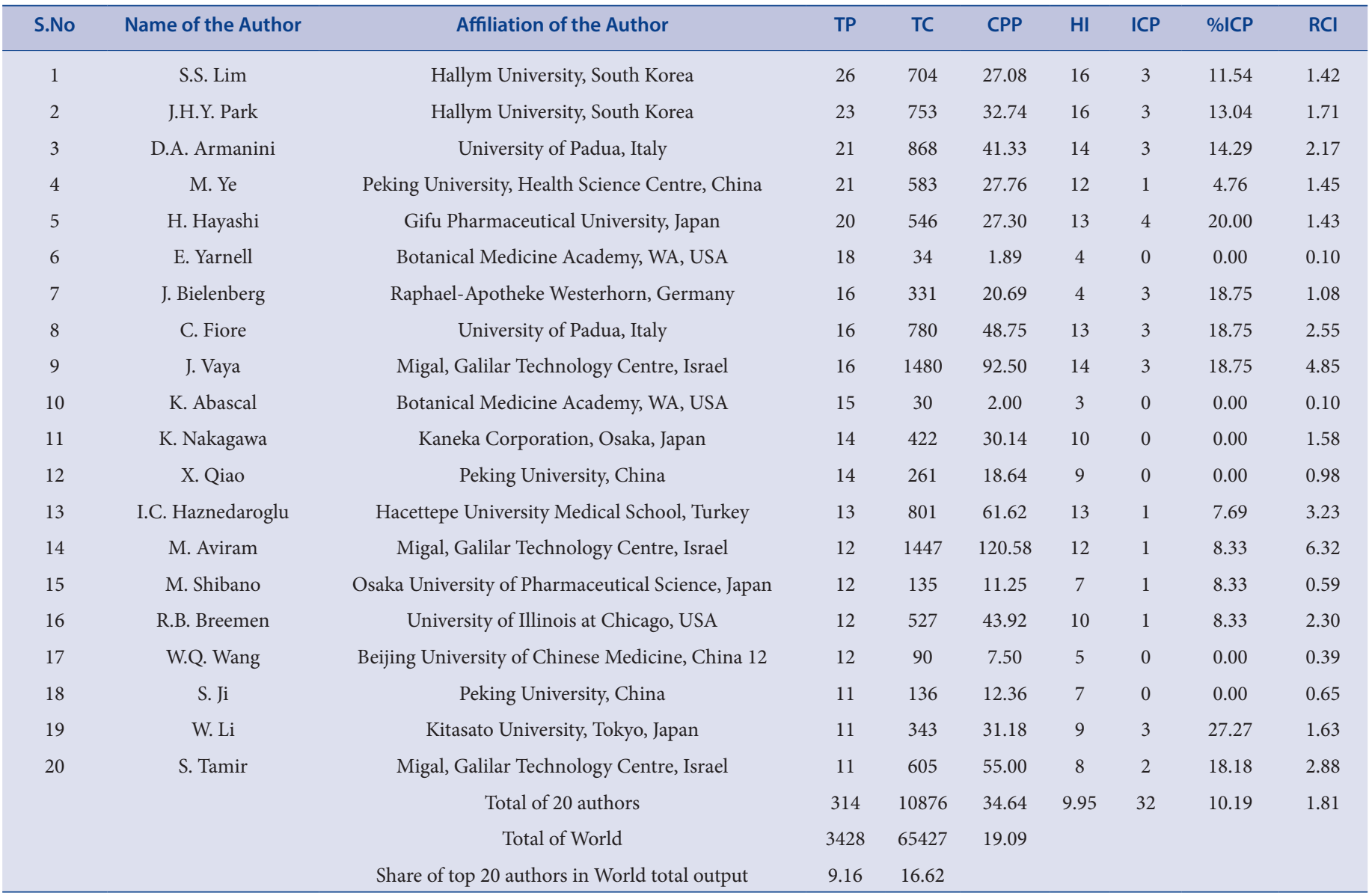

TP=Total Papers; TC=Total Citations; CPP=Citations Per Paper; HI=h-index; ICP=International Collaborative Papers; RCI=Relative Citation Index

nal of Agricultural and Food Chemistry and Zhongguo Zhongyao Zachi (43 papers each), Biological and Pharmaceutical Bulletin (37 papers), etc. during 1997-16 (Table 6).

\section{SIGNIFICANT KEYWORDS}

Around 133 significant keywords have been identified from the literature which through lighton the research trends in Glycyrrhiza glabra researchincluding its pharmacological properties and medicinal uses. These keywords are listed in Table 8 in the decreasing order of the frequency of their occurrence in the literature during 1997-2016.

\section{HIGHLY CITED PAPERS}

A total of 113 highly cited papers were identified each having 100 to 852 citations (82 papers each in citation range 100-200, 17 papers each in 201300 citations range, 5 papers each in 301-400 citations range, 3 papers each in 401-500 citations range, 2 papers each in 501-600 citations range, 3 papers each in 601-700 citations range and 1 paper 852 citations) in 20 years during 1997-2016. Together these 113 papers cumulateda total of 22234 citations, averaging 196.76 citations per paper. Of the 113 highly cited papers, 49resulted from theparticipation of research organizationsin their roleas stand-alone (non-collaborating) institutional authorsand remaining 64from two or more research organizationsworking in their role as collaborating partners per paper (42 national collaborative and 22 international collaborative). Among 113 highly cited papers, the largest participation was seen from USA (29 papers), followed by the U.K. (13 papers), Japan (11 paper), Israel (10 papers), India and Italy (9 papers each), China (8 papers), Germany (7 papers), South Korea and Canada (4 papers each), Iran, Turkey, Netherlands, Australia, Spain and Switzerland 92 papers each), etc. These 113 highly cited papers involved the participation of 444 personal authors and 236 research organizations in total across globe. Of the 113 highly cited papers, 62 were published as articles, 42 as reviews papers, 5 as conference papers and 4 as short surveys. These 113 highly cited papers were published in 80 journals, with 10 papers in Journal of Ethnopharmacology, 6 papers in Journal of Agricultural and Food Chemistry, 4 papers in Phytotherapy Research, 3 papers in Phytomedicine, 2 papers each in American Journal of Health-System Pharmacy, Applied Microbiology and Biotechnology, Archives of Internal Medicine, Atherosclerosis, Food Chemistry, Free Radical Biology and Medicine, Journal of Chromatography A, Journal of Steroid Biochemistry and Molecular Biology, Lancet, Life Sciences, Menopause and Phytochemistry and 1 paper each in 64 other journals.

\section{CONCLUSION}

Research publications data sourced from the Scopus database was analysed in this study to provide a quantitative and qualitative description of global Glycyrrhiza glabra research covering 20 years period, 1997-2016. The study showed that annual and ten-year cumulative global output of Glycyrrhiza glabra research registered $10.87 \%$ and $180.47 \%$ growth. Itsglobal citation impact averaged to 19.09 citations per paper in 20 years, which decreased from 38.67 to 12.10 from 1997-2006 to 2007-16.

More than $40 \%$ of global Glycyrrhiza glabra research output share was mainly from China, India and USA, whereas other 9 top ranking coun- 
Table 6: Top 20 Most Productive Journals in Glycyrrhiza glabra Research during 1997-16

\begin{tabular}{|c|c|c|c|c|}
\hline \multirow[t]{2}{*}{ S.No } & \multirow[t]{2}{*}{ Name of the Journal } & \multicolumn{3}{|c|}{ Number of Papers } \\
\hline & & 2007-11 & 2012-16 & 2007-16 \\
\hline 1 & Journal of Ethnopharmacology & 21 & 43 & 64 \\
\hline 2 & Phototherapy Research & 10 & 40 & 50 \\
\hline 3 & $\begin{array}{l}\text { Journal of Agricultural and } \\
\text { Food Chemistry }\end{array}$ & 16 & 27 & 43 \\
\hline 4 & Zhongguo Zhongyao Zachi & 9 & 34 & 43 \\
\hline 5 & $\begin{array}{c}\text { Biological and Pharmaceutical } \\
\text { Bulletin }\end{array}$ & 22 & 15 & 37 \\
\hline 6 & Phytomedicine & 17 & 13 & 30 \\
\hline 7 & $\begin{array}{c}\text { Chinese Journal of Clinical } \\
\text { Rehabilitation }\end{array}$ & 28 & 0 & 28 \\
\hline 8 & Planta Medica & 6 & 20 & 26 \\
\hline 9 & $\begin{array}{l}\text { Evidence-based } \\
\text { Complementary and } \\
\text { Alternative Medicine }\end{array}$ & 1 & 24 & 25 \\
\hline 10 & $\begin{array}{c}\text { Chinese Traditional and } \\
\text { Herbal Drugs }\end{array}$ & 1 & 22 & 23 \\
\hline 11 & $\begin{array}{l}\text { International Journal of } \\
\text { Pharma and Bio Sciences }\end{array}$ & 0 & 22 & 22 \\
\hline 12 & $\begin{array}{c}\text { International Journal of } \\
\text { Pharmacy and Pharmaceutical } \\
\text { Sciences }\end{array}$ & 0 & 21 & 21 \\
\hline 13 & PLOS One & 0 & 21 & 21 \\
\hline 14 & Food Chemistry & 2 & 18 & 20 \\
\hline 15 & $\begin{array}{c}\text { Alternate and Complementary } \\
\text { Therapies }\end{array}$ & 3 & 16 & 19 \\
\hline 16 & Journal of Separation Science & 2 & 17 & 19 \\
\hline 17 & $\begin{array}{c}\text { International } \\
\text { Immunopharmacology }\end{array}$ & 5 & 12 & 17 \\
\hline 18 & Journal of Chromatography A & 4 & 13 & 17 \\
\hline 19 & Photochemistry & 14 & 3 & 17 \\
\hline \multirow[t]{4}{*}{20} & Fitoterapia & 5 & 11 & 16 \\
\hline & Total of 20 journals & 166 & 392 & 558 \\
\hline & Total global journal output & 886 & 2436 & 3322 \\
\hline & $\begin{array}{l}\text { Share of top } 20 \text { journals in } \\
\text { global journal output }\end{array}$ & 18.74 & 16.09 & 16.80 \\
\hline
\end{tabular}

tries accounted each forglobal share between $1.87 \%$ and $8.66 \%$ during 1997-206. The top 12 most productive countries in Glycyrrhiza glabra research together accounted for a high of $79.18 \%$ global share during 1997-2016, which decreased from $100.0 \%$ to $77.80 \%$ from $1997-2006$ to 2007-16.Top ranking Asian countries in Glycyrrhiza glabra researchdominate in quantity of research whereas American and western countries in the ranking list dominate more in quality of research. For example, China, India, Japan, South Korea, Iran and Taiwan from Asia together accounted for $56.42 \%$ global share and citation impact (averaging 18.46 citations per paper) and comparatively the USA, Germany, Italy, the U.K., Turkey and Canada account for $25.22 \%$ global share and citation impact (averaging 31.28 citations per paper) during 1997-2016. The global publication share registered a decreasing publication share in 11 countries (except for Iran) varying from $0.83 \%$ to $4.76 \%$ in 11 out of 12 countries from 1997-2006 to 2007-17. Of the top 12 countries, seven registered relative citation index above the world average of 1.10: U.K. (2.39), USA (1.87), Canada (1.71), Italy (1.51), Japan (1.49), Turkey (1.24) and Taiwan (1.18) during 1997-2018. The international collaborative publicationshare of American and western countries in Glycyrrhiza glabra was greater ( $21.77 \%$ to $42.55 \%$ share) compared to that of Asian countries (6.12\% to $19.19 \%$ share).

Medicine was the most sought after subject area of Glycyrrhiza glabra research, accounting for (44.41\%) the highest publications share, followed by pharmacology, toxicology and pharmaceutics (35.04\%), biochemistry, genetics and molecular biology (26.84\%), agricultural and biological sciences (16.89\%), chemistry (14.59\%), etc. during 1997-16. Among broad subjects, the research activities registered increase in pharmacology, toxicology and pharmaceutics, agricultural and biological sciences, chemistry, immunology and microbiology, chemical engineering, environmental science, engineering, neurosciences, dentistry and veterinary science, as against decline in medicine and biochemistry, genetics and molecular biology from 1997-2006 to 2007-16. Biochemistry, genetics and molecular biology, among various subjects registered the highest citations impact per paper, followed by chemistry, immunology and microbiology, neurosciences, environmental science, pharmacology, toxicology and pharmaceutics, medicine, agricultural and biological sciences, chemical engineering, dentistry, engineering and veterinary science during 1997-16.

The top 20 most productive research organizations and the authors on Glycyrrhiza glabra research collectively contributed $15.08 \%$ and $9.16 \%$ global publication share and $14.57 \%$ and $16.62 \%$ global citation sharerespectively during 1997-16. The leading organizations in terms of publication productivity were: Beijing University of Chinese Medicine, China (46 papers), Hallym University, South Korea (39 papers), Seoul National University, South Korea (37 papers), Tehran University of Medical Sciences, Iran (34 papers), China Pharmaceutical University, China (29 papers), Peking University, China (28 papers), University of Illinois at Chicago, USA (26 papers), etc during 1997-2016. The leading organizations in terms of citation impact per paper were: University of Padua, Italy (38.57), Gifu Pharmaceutical University, Japan (37.55), University of Illinois at Chicago, USA (34.08), Hallym University, South Korea (29.08), Kaneka Corporation, Osaka, Japan (26.70), Tehran University of Medical Sciences, Iran (25.53), Seoul National University, South Korea (22.0), Korea Food Research Institute, South Korea (20.19), China Pharmaceutical University, China (19.69), China Medical University Taichung, Taiwan (18.52), etc. during 1997-2016.

The journals medium accounted for $96.91 \%$ global share in Glycyrrhiza glabra research with top 20 most productive journals accounting for $16.80 \%$ of total publications output in journals during 1997-2016. Journal of Ethnopharmacology contributed the largest number of papers(64), Phototherapy Research (50 papers), Journal of Agricultural and Food Chemistry and Zhongguo Zhongyao Zachi (43 papers each), Biological and Pharmaceutical Bulletin (37 papers), etc during 1997-2016

Conclusively, this research study reveals that Asian countries dominate in Glycyrrhiza glabra research more in terms of quantity of research, whereas American and western countries dominate instead more in terms of quality of research. For enabling Asian counties to perform better interms of citation impact, it is suggested that the participating Asian countries shouldgive higher priority to Glycyrrhiza glabra researchand encourage its leading academic and research organizations to participate in international collaboration with counterparts from western countries. Licorice (Glycyrrhiza glabra) root and its extract such as glycyrrhizin have a long history of use in traditional medicines, folk remedies, and as a sweetening and flavoring agent. The present study analyzed chemical, traditional use,bioactive constituents and pharmacologic activities and medicinal aspects of Glycyrrhiza glabra. Such an analays is will help 
Table 8: List of Significant Keywords in Literature on Global Aloe Vera Research during 2007-16.

\begin{tabular}{|c|c|c|c|c|c|c|c|c|}
\hline S.No & Keyword & Frequency & S.No & Keyword & Frequency & S.No & Keyword & Frequency \\
\hline 1 & Glycyrrhiza & 1616 & 41 & Liquiritin & 122 & 81 & Jaundice & 16 \\
\hline 2 & Glycyrrhiza glabra & 932 & 42 & Liquorice & 122 & 82 & Weight Gain & 16 \\
\hline 3 & Plant Extract & 696 & 43 & Genetics & 109 & 83 & Radiation Exposure & 15 \\
\hline 4 & Glycyrrhizic Acid & 590 & 44 & Anti-Bacterial Activity & 104 & 84 & Immune System & 14 \\
\hline 5 & Glycyrrhiza glabra Extract & 562 & 45 & & & 85 & Radiation Injury & 14 \\
\hline 6 & Herbaceous Agent & 463 & 46 & Ginger & 104 & 86 & Tacrolimus & 14 \\
\hline 7 & Medicinal Plant & 555 & 47 & Ginseng & 103 & 87 & Fatty Liver & 13 \\
\hline 8 & Plant Root & 430 & 48 & Liver & 99 & 88 & Ulcer Healing & 13 \\
\hline 9 & Licorice & 424 & 49 & Cell Line, Tumor & 98 & 89 & Radiation Doss & 11 \\
\hline 10 & Drug Effect & 383 & 50 & $\begin{array}{c}\text { Randomised Control } \\
\text { Trials }\end{array}$ & 96 & 90 & Ultrasound & 11 \\
\hline 11 & Glycyrrhiza Extract & 361 & 51 & Gene EXpression & 94 & 91 & Hair Loss & 9 \\
\hline 12 & Metabolism & 323 & 52 & Pathology & 94 & 92 & Hair Growth & 8 \\
\hline 13 & Glycyrrhetinic Acid & 322 & 53 & Cytotoxcity & 93 & 93 & Vasomotor Disorder & 8 \\
\hline 14 & Drug Efficacy & 292 & 54 & Anti-Viral Activity & 81 & 94 & Vancomycin & 8 \\
\hline 15 & Glycyrrhiza Uralensis & 286 & 55 & Fabacea & 97 & 95 & Female Infertility & 7 \\
\hline 16 & Phototherapy & 277 & 56 & Macrophage & 65 & 96 & Occupational & 7 \\
\hline 17 & Drug Mechanism & 262 & 57 & Obesity & 47 & 97 & Ultrasonic & 7 \\
\hline 18 & Flavonoid & 256 & 58 & Kidney & 46 & 98 & Vaginitis & 7 \\
\hline 19 & Anti-Oxidant Activity & 254 & 59 & Fatique & 43 & 99 & Vascular Disease & 7 \\
\hline 20 & Hypertension & 254 & 60 & Kidney Disease & 39 & 100 & Kidney Cancer & 6 \\
\hline 21 & Herbal Medicine & 250 & 61 & Pain & 39 & 101 & Olfaction Disorders & 6 \\
\hline 22 & $\begin{array}{l}\text { High Performance Liquid } \\
\text { Chromatography }\end{array}$ & 250 & 62 & Quercetin & 38 & 102 & Palliative Therapy & 6 \\
\hline 23 & Anti-Inflammatory Activity & 214 & 63 & Immune Response & 30 & 103 & Radiation Dermatitis & 6 \\
\hline 24 & Protein Expression & 207 & 64 & Ulcer & 26 & 104 & Radioimmunoassay & 6 \\
\hline 25 & Enzyme Activity & 201 & 65 & Ultraviolet Radiation & 26 & 105 & Vascular Endothelium & 6 \\
\hline 26 & Glycyrrhizin & 195 & 66 & Echinacea & 25 & 106 & Fat & 5 \\
\hline 27 & Drug Structure & 191 & 67 & Abdominal Pain & 24 & 107 & Gall Bladder Disease & 5 \\
\hline 28 & Drug Effects & 189 & 68 & Dandelion & 24 & 108 & HIV & 5 \\
\hline 29 & Apoptosis & 155 & 69 & Magnesium & 24 & 109 & Hair Follicle & 5 \\
\hline 30 & Chinese Medicine & 155 & 70 & Ochratoxin & 24 & 110 & Rabdosia & 5 \\
\hline 31 & Antioxidants & 154 & 71 & Quality of LIfe & 24 & 111 & Ear Infection & 4 \\
\hline 32 & Glabridin & 153 & 72 & Odor & 23 & 112 & Femur & 4 \\
\hline 33 & Anti-Neoplastic Activity & 150 & 73 & Techycardia & 23 & 113 & Nail Disease & 4 \\
\hline 34 & Clinical Trial & 147 & 74 & Daidzein & 22 & 114 & $\begin{array}{c}\text { Upper Gastrointestinal } \\
\text { Bleeding }\end{array}$ & 4 \\
\hline 35 & Drug Screening & 141 & 75 & Oat & 20 & 115 & Ear Diseases & 3 \\
\hline 36 & Oxidation Stress & 140 & 76 & Vasculotropin & 20 & 116 & Facial Dermatosis & 3 \\
\hline 37 & Drug Safety & 136 & 77 & Fatty Acids & 19 & 117 & $\begin{array}{l}\text { Kidney Failure, } \\
\text { Chronic }\end{array}$ & 3 \\
\hline 38 & Phytochemistry & 127 & 78 & Weight Gain & 19 & 118 & KidneyFibrosis & 3 \\
\hline 39 & Inflammation & 125 & 79 & Tamoxifen & 19 & 119 & Facial Nerve Paralysis & 2 \\
\hline 40 & Traditional Medicine & 124 & 80 & Immune Deficiency & 16 & & & \\
\hline
\end{tabular}


in undertaking further studies on Glycyrrhiza glabran for exploring its potential in preventing and treating diseases. It will also give direction for future investigators to carry out research in discovering potential therapeutic effects and developing new formulations.

\section{REFERENCES}

1. Phytochemicals. N.d. http://shodhganga.inflibnet.ac.in/bitstream/ 10603/18546/ 9/09_chapter \% 201Pdf (Accessed on 5 May 2018)

2. Glycyrrhiza 22 March 2018. https://en.wikipedia.org/wiki/Glycyrrhiza(Accessed on 5 May 2018)

3. Glycyrrhiza glabra L. http://powo.science.kew.org/taxon/urn:Isid:ipni. org:names:496941-1(Accessed on 5 May 2018)

4. Zadeh,Jalal B, Kor, Zahra M, Goftar,Masoud K. Licorice (Glycyrrhiza glabra Linn) as a valuable medicinal Plant. International journal of Advanced Biological and Biomedical Research. 2013;1(10):1281-5.

5. Glycyrrhiza glabra. http://vikaspedia.in/agriculture/crop-production/package-ofpractices/medicinal-and-aromatic-plants/glycyrrhiza-glabra-1
6. Kaur, Rajandeep, Kaur, Harpreet K, Dhindsa,Ajaib S. Glycyrriza glabra: A Phytopharmacological review. International Journal of Pharmaceutical Sciences and Research.2013;7(4):2470-7.

7. Ram S. A bibliometric assessment of the liquorice (Glycyrrhiza glabre) research trends. Annals of Library and Information Studies. 2015;62(1):27-32.

8. Gupta BM, Mueen Ahmed KK, Dhawan SM, Gupta R. Aloe Vera (Medicinal Plant) research: A scientometric assessment of global publications output during 2007-16. Pharmacognosy Journal. 2018;10(1):1-8.

9. Yao Q, Chen J, Lyu PH, Zhang SJ, Ma FC, Fang JG. Knowledge map of artemisinin research. Journal of Vector Borne Diseases.2012;49:205-16.

10. Nirmal S. Scientific output on Azadirachta indica (Neem): A bibliometric study. SRELS Journal of Information Management.2016;53(6):479-85.

11. Anwar MA. Phonix DL.A bibliometric study of the literature on Date Palm. Malaysian Journal of Library and Information Science.2006;11(1):41-60.

12. Alhaider I, Ahmed MKK, Gupta BM. Global research output on date palm (Phonix dactyl lifra): A 12 years scientometric perspective. Scientometrics.2013;94(3):157-71.

Cite this article: Gupta BM, Mueen Ahmed KK, Gupta R. Glycyrrhiza glabra (Medicinal Plant) Research: A Scientometric Assessmentof Global Publications Output during 1997-2016. Pharmacog J. 2018;10(6):1067-75. 